\title{
Plainclothes Policewomen on the Trail: NYPD Undercover Investigations of Abortionists and Queer Women, 1913-1926
}

\author{
Elizabeth Evens (D)
}

In early twentieth-century New York City, policewomen went undercover to investigate abortion and queer women. These early female entrants to the New York Police Department were not the middle class reformers typically associated with Progressive Era vice reform; they tended to be working class white widows who carved out a gendered expertise that relied upon their unique capacity and willingness to extend surveillance over the female, immigrant spaces that eluded their male counterparts. The NYPD instrumentalized policewomen's bodies; investigations of criminalized female sexuality required policewomen participate in intimate encounters, exposing their own precarity in the masculine world of policing. But plainclothes work also furnished policewomen with a rare route to professional renown and social mobility, "success" they won at the expense of more marginalized women. Their work reveals that the early twentieth-century state was more innovative and invested in methods to police "disorderly" female heterosexuality and same sex desire than previously understood.

"Women criminals sometimes 'get away with it' when only the men police officers are involved by the artful use of their feminine charms," complained prominent journalist and public administrator Louis Brownlow in 1927; "I have known it to happen." But, "not so when the policewoman is on the trail," he proclaimed. Brownlow captured the logic underpinning early policewomen's success within the profession-their capacity and willingness to increase surveillance of other women. "Some forms of crime," he continued, "are more or less the special business of women criminals, and in this field the policewoman often is able to do quicker and more effective work than men police officers"- a dynamic most evident in investigations of criminalized female sexuality, including abortion and same sex desire. By employing women investigators, municipal police extended the state's gaze into feminine spaces hitherto hidden from sight. Crucially, policewomen themselves benefited from their gendered expertise. In the New York Police Department (NYPD), the first female investigators were working class matrons furnished with a rare route to meaningful social mobility at the expense of women already marginalized. The foremost journal of women in policing reprinted Brownlow's article that concluded: "her feet may not be flat, but the policewoman is not a bad detective."

NYPD women developed undercover techniques around the turn of the twentieth century, honed them through investigations of abortion, and later extended these methods to police queer women. From 1913, white policewomen led the regulation of abortion in New York City primarily through plainclothes investigations in which they used language, clothing,

Thank you to the Modern American History team-Sarah Phillips, Brooke Blower, and the editorial assistants-as well as the anonymous reviewers. This research owes much to Jonathan Bell and Mara Keire, to those at the New York Municipal Archives, and to Barbara Kahn and Jonathan Ned Katz, who extensively researched and generously shared Eve Adams' story with me. This article was completed with the financial support of the Wolfson Foundation.

${ }^{1}$ Louis Brownlow, "The Policewoman and the Criminal," National Municipal Review 16, no. 7 (July 1927), extracts reprinted in "The City and Citizen," International Association of Women in Policing Bulletin 3, no. 34 (Nov.-Dec. 1927), reel ZAN-10352, Periodicals and Microform records, New York Public Library.

(C) The Author(s) 2020. Published by Cambridge University Press 
and narrative to pose as women with untenable pregnancies in order to target midwives from central, southern, and eastern Europe. ${ }^{2}$ Yet, this process also imperiled policewomen's own moral and sexual reputations. During investigations they received invasive pelvic exams and later testified about these intimate procedures before all-male grand juries and the court of general sessions. Having made themselves indispensable to policing, they adapted plainclothes techniques according to heightened regulation of queer nightlife and the intensification of the federal deportation machinery in the 1920s.

Policewomen were critical, but often overlooked, arbiters of urban sexual mores during the Progressive Era. In the substantial literature on moral reform in New York City, historians have argued that because of political and police corruption, it fell to private reform groups to define and enforce moral order. Scholarship has focused on how organizations such as the Committee of Fourteen, the Society for the Suppression of Vice, and the Rockefeller Grand Jury controlled sex work, homosexuality, and birth control. ${ }^{3}$ Policewomen's work reveals that the state was more innovative and invested in methods to police criminalized female heterosexuality and same sex desire than previously understood.

Although women are familiar figures in the urban reform landscape, historians have focused on their roles as middle-class philanthropic volunteers or as college-educated social workers who harnessed welfare policy for reform. A generation of historians of the gendered welfare state grappled with how these women also used assistance as an instrument of social control. ${ }^{4}$ However, women's use of punitive tools is less studied. ${ }^{5}$ As in welfare, male administrators were more likely to cede professional territory in matters relating to women and their criminality. ${ }^{6}$ Informed by this perceived gendered divide between welfare and punitive work, histories of policewomen have presented them as "nurturant" social workers or "municipal mothers."7

\footnotetext{
${ }^{2}$ The NYPD applied women's police titles inconsistently. For clarity, I use "policewoman" to refer to NYPD women who performed investigative work. Most of these women retained the rank of "matron" until 1919, but their work was distinct from the care of the stationhouse and many were temporarily assigned to other NYPD squads. On the connection between policing midwifery and abortion, see Leslie Reagan, "Linking Midwives and Abortion in the Progressive Era," Bulletin of the History of Medicine 69, no. 4 (Winter 1995): 569-98.

${ }^{3}$ Timothy J. Gilfoyle, “The Moral Origins of Political Surveillance: The Preventive Society in New York City, 1867-1918," American Quarterly 38, no. 4 (Autumn 1986): 637-52. Also on the Society for the Suppression of Vice, see Nicola Kay Beisel, Imperiled Innocents: Anthony Comstock and Family Reproduction in Victorian America (Princeton, NJ, 1997). On the Committee of Fourteen, see George Chauncey, Gay New York: Gender, Urban Culture, and the Making of the Gay Male World, 1890-1940 (New York, 1994); and Mara L. Keire, For Business \& Pleasure: Red-Light Districts and the Regulation of Vice in the United States, 1890-1933 (Baltimore, MD, 2010). For recent scholarship considering the Rockefeller Grand Jury investigations, see Brian Donovan and Tori Barnes-Brus, "Narratives of Sexual Consent and Coercion: Forced Prostitution Trials in Progressive-Era New York City," Law and Social Inquiry 36, no. 3 (Summer 2011): 597-619.

${ }^{4}$ Gwendolyn Mink, "The Lady and the Tramp: Gender, Race, and the Origins of the American Welfare State," in Women, the State, and Welfare, ed. Linda Gordon (Madison, WI, 1990), 103; Robyn Muncy, Creating a Female Dominion in American Reform, 1890-1935 (New York, 1991), 113, 115-6; Gwendolyn Mink, The Wages of Motherhood: Inequality in the Welfare State, 1917-1942 (London, 1995), 178.

${ }^{5}$ A notable exception is Mary Odem, Delinquent Daughters: Protecting and Policing Adolescent Female Sexuality in the United States, 1885-1920 (Chapel Hill, NC, 1995). For analysis of women's regulatory work on Ellis Island, see Val Marie Johnson, "Protection, Virtue, and the 'Power to Detain': The Moral Citizenship of Jewish Women in New York City, 1890-1920," Journal of Urban History 31, no. 5 (Jul. 2005): 655-84; and Jessica Pliley, “The Petticoat Inspectors: Women Boarding Inspectors and the Gendered Exercise of Federal Authority," Journal of the Gilded Age and Progressive Era 12, no. 1 (Jan. 2013): 95-126. Johnson and Jennifer Fronc examined undercover women in the Committee of Fourteen's Macy's Department Store investigation in Val Marie Johnson, "Look for the Moral and Sex Sides of the Problem': Investigating Jewishness, Desire, and Discipline at Macy's Department Store, New York City, 1913," Journal of the History of Sexuality 18, no. 3 (Sep. 2009): 457-85; and Jennifer Fronc, New York Undercover: Private Surveillance in the Progressive Era (Chicago, 2009), 63-95.

${ }^{6}$ Muncy, Creating a Female Dominion, xv.

${ }^{7}$ Dorothy Schulz described the "nurturant roles first carved out by early policewomen," in "A Precinct of Their Own: The New York City Women’s Precinct, 1921-1923,” New York History 85, no. 1 (Winter 2004): 39-64. See
} 
Historian Mary Odem, however, in 1995 called for scholars to recognize how "the professional success and status of early police women rested on their control and surveillance of other women's sexuality and social behavior." 8 In the two decades since Odem's call, this connection has become even more urgent as activists and academics have theorized "carceral feminism," which delineated how some women encouraged and legitimized the expansion of state power in the late twentieth century under the guise of claiming new protections for women. ${ }^{9}$ These theorizations demand a reckoning with the longer history of white women's complicity in and collusion with the carceral state. In this article, I demonstrate how the first-wave feminist goal to see women enter male-dominated professions and government institutions harmonized with the aims of moral regulators, who wished to extend their reach into female immigrant spaces that had hitherto eluded them.

The historical oversight of policewomen's work stems, in part, from the notorious sparsity of policing records due to self-censorship and, in New York City, the accidental destruction of the policing museum. ${ }^{10}$ I use newly catalogued district attorney felony indictments (1916-1925) held at the New York Municipal Archives. ${ }^{11}$ These documents vary in scope; some files contain only affidavits listing demographic information about the accused, while other records include correspondence, physical evidence, interview transcripts, and other material gathered by police and prosecutors. I read these sources alongside trial transcripts from the court of general sessions, police reports, and municipal correspondence to document how policewomen's bodies became a conduit for the policing of urban immigrant populations in the Progressive Era. An analysis of policewomen's undercover work illuminates how they carved out a unique role in controlling other women's sexuality and reproduction. ${ }^{12}$ New York policewomen surveilled immigrant midwives, coerced working class women to testify in abortion trials, and, in the 1920s, applied these methods to criminalize queer women. This work represented white women's installation as agents in the carceral state.

\section{Plainclothes Police Matrons}

In the late nineteenth century, middle class voluntarist women mobilized around issues of female criminality by calling for institutional change in policing and prisons. Organizations like the Women's Christian Temperance Union and the Women's Prison Association

also Gloria Myers, A Municipal Mother: Portland's Lola Greene Baldwin, Americas First Policewoman (Corvallis, OR, 1995).

${ }^{8}$ Mary E. Odem, Review of From Social Worker to Crime Fighter: Women in United States Municipal Policing, by Dorothy Moses Schulz, and A Municipal Mother: Portland's Lola Greene Baldwin, America's First Policewoman, by Gloria E. Myers, American Historical Review 102, no. 2 (Apr. 1997): 538-9.

${ }^{9}$ Elizabeth Bernstein, "Carceral Politics as Gender Justice? The 'Traffic in Women' and Neoliberal Circuits of Crime, Sex, and Rights," Theory and Society 41, no. 3 (May 2012): 233-59; Victoria Law, "Against Carceral Feminism," Jacobin Magazine, Oct. 17, 2014, https://www.jacobinmag.com/2014/10/against-carceral-feminism/ (accessed Nov. 18, 2019); Molly Smith and Juno Mac, Revolting Prostitutes: The Fight for Sex Workers' Rights (London, 2018), 22-33; Denise Tomasini-Joshi, asha bandele, Victoria Law, Mariame Kaba, and Erin Cloud, "Finding Justice for Victims in the \#MeToo Era," Mar. 6, 2018, Open Society Foundations Recording, http:// www.opensocietyfoundations.org/voices/finding-justice-for-victims-in-the-metoo-era (accessed Jan. 9, 2020).

${ }^{10}$ Matthew Guariglia, "What the Loss of the New York Police Museum Means for Criminal Justice Reform," Washington Post, May 22, 2019, https://www.washingtonpost.com/outlook/2019/05/22/what-loss-new-yorkpolice-museum-means-criminal-justice-reform/ (accessed May 28, 2019).

${ }^{11}$ New York District Attorney Indictments (1916-1925) at the New York Municipal Archives, New York [hereafter NYMA, DA], became available in 2014 following a grant from the National Endowment of the Humanities to rehouse, index, and create a digital database for over 60,000 indictments.

${ }^{12}$ Histories of policewomen usually rely on published writings and philosophies, written by policewomen themselves and middle-class reform women. When scholar Janis Appier did examine case files in her study of LAPD policewomen, she complicated the idea of "mothers to all" advanced elsewhere in Policing Women: The Sexual Politics of Law Enforcement at the LAPD (Philadelphia, 1998), 109. 
envisioned appointing white female matrons as a means of injecting moral propriety into the disorderly, mixed-gender stationhouse and improving the treatment of incarcerated women. The first matrons entered New York prisons in the mid-nineteenth century, but reformers gained renewed impetus in subsequent decades following high profile cases of male officers' sexual misconduct. With this momentum, the New York State governor signed a bill in 1892 pledging to install matrons to all stationhouses. ${ }^{13}$

Isabella Goodwin was typical of this first generation of matrons. Born in 1865 to a working-class family in Greenwich Village, in 1885 she married NYPD roundsman John Goodwin and the pair had four children at the time of John's death just eleven years later. Thirty-one years old, widowed, and needing to support her family, Goodwin took the civil service exam and became a matron at Mercer Street station in 1896. As opposed to the genteel prison reformers, early matrons tended to be working-class white women, many were widows, and they often possessed family traditions of policing. Some matrons were first- or second-generation immigrants from Western Europe, while African American, Jewish, and Italian applicants faced discrimination in the civil service entrance exam. ${ }^{14}$ For eligible applicants, the matron position offered financial and job security, a connection to familial ties in policing, and a rare route to meaningful social mobility.

But matron work was physically demanding and took place in testing environments. Matrons spent long shifts, during the day and overnight, in poorly maintained, uncomfortable stationhouses. Here they searched the bodies of female detainees, dealt with intoxicated women and rough sleepers, and managed overcrowded cells. In addition to these tasks, they tended to children who were temporarily and permanently lost by their parents, as well as to sick women awaiting medical attention. The laborious nature of this work made it unappealing to middleclass women. The introduction of matrons also coincided with an increase in the number of women arrested by the NYPD. Perhaps policemen felt more comfortable detaining women with the knowledge that they would enter a matron's custody. ${ }^{15}$ From these beginnings, women's presence furthered the ability of municipal police to regulate female residents.

Most matrons spent their police careers within the stationhouse, but a small number of opportunistic matrons sought new duties, at first within the precinct by assisting on investigations involving women and children in police custody, drawing upon perceived feminine expertise. Mary Sullivan became a matron in Harlem in 1911 and swiftly sought new work by earning the confidence of female detainees to elicit key details of crimes. In her autobiography entitled My Double Life-a nod to the importance of undercover work to policewomen's professional identities-Sullivan alleged that some "women prisoners very much resented my presence among the detectives" as "I ruined the coquettish role which feminine prisoners and witnesses often like to assume and which the men usually encourage." ${ }^{\prime 6}$ This prowess led her outside the stationhouse to extend NYPD surveillance into female spaces. ${ }^{17}$ Police

\footnotetext{
${ }^{13}$ Estelle Freedman, Their Sisters' Keepers: Women's Prison Reform in America, 1830-1930 (Ann Arbor, MI, 1981); Mary Aldrich-Moodie, "Staking Out Their Domain: Women in the New York City Police Department, 1890-1935” (Ph.D. diss., University of North Carolina, 2002), 23, 27-9.

${ }^{14}$ Of those who worked on abortion cases, one woman was an Irish immigrant, one had Irish grandparents, and the other was born in New York to parents from the German speaking Alsace-Lorraine. The first Black, Irish, and Jewish policewomen were hired in 1919 by bypassing the civil service exam, discussed later in the article. On discriminatory recruitment processes, see James Lardner and Thomas Reppetto, NYPD: A City and Its Police (New York, 2000), 139-40.

${ }^{15}$ This is the subject of chapters 1 and 2 of Aldrich-Moodie, "Staking out Their Domain," 11-93, 35. See also, Dorothy Moses Schulz, "The Police Matron Movement: Paving the Way for Policewomen," Police Studies: The International Review of Police Development 12, no. 3 (1989): 115-24; "What the Matron Does," The Sun, Nov. $1,1891,25$.

${ }^{16}$ Mary Sullivan, My Double Life: The Story of a New York Policewoman (New York, 1938), 85.

${ }^{17}$ On the NYPD's employment of Charles Dancy, a Black informant, to surveil Black communities, see LaShawn D. Harris, "Women and Girls in Jeopardy by His False Testimony': Charles Dancy, Urban Policing, and Black Women in New York City during the 1920s," Journal of Urban History 44, no. 3 (2018): 457-75.
} 
headquarters did not issue a coherent policy on this work; rather, women "made their own jobs" by rendering themselves indispensable. For ambitious matrons, these ad hoc investigations became their only route to promotion. Upon her appointment to the detective bureau, Sullivan proudly reflected that "the tiresome, confining days of sitting in the rear of Clinton Street stationhouse were over at last." 18

Policewomen adopted plainclothes to gain information and to catch suspects in the commission of a crime. Undercover work was an existing part of the turn-of-the-century professional woman's toolkit. Female journalists, most infamously Nellie Bly in her 1887 New York World exposé of the women's lunatic asylum at Blackwell Island, showed how gendered undercover tasks offered women a rare route to professional renown. Longstanding gender ideologies informed a belief in feminine powers of observation and knowledge of women's networks, and these powers gained new importance in private reform initiatives. Organizations like the New York Probation and Protective Association and Big Sisters movement, in addition to groups devoted to specific communities such as the Young Women's Hebrew Association, relied upon female-led surveillance. ${ }^{19}$ Mary Sullivan situated policewomen's undercover work within traditions of gendered expertise to stress its skilled nature. She argued that policewomen needed to be more than investigators: they needed to possess the observation and notetaking skills of a reporter; the language abilities of an accomplished linguist; and the character work, costumes, and vocal abilities of an actress. ${ }^{20}$

In the 1910s, the NYPD increasingly relied upon matrons' sleuthing skills to resolve a range of cases, particularly those affecting women. Practicalities partially inspired this system, as men could not convincingly pose as victims of certain crimes. Additionally, as a minority presence on the police, women aroused less suspicion; their femininity masked their state-given regulatory power. ${ }^{21}$ Newspapers widely reported tales of female sleuths catching criminals, albeit often in a cartoonish tone. In one of her many investigations of fortune tellers, Isabella Goodwin posed as the childhood sweetheart of clairvoyant Frank Henry Wolf, who targeted widows and duped them into investing in a fake stock company. She "gushed for a year to reach alleged swindler's heart," proclaimed one news story under the headline "Mrs. Goodwin's Love Lure Led to Prison." ${ }^{22}$ Newspapers conflated policewomen's personal and professional lives to titillate their readers. ${ }^{23}$ When Goodwin remarried in 1921, The Sun announced that Goodwin "changed her name again, as she frequently has done in the past, but this time not for police reasons." ${ }^{24}$ Such reporting showed the centrality of undercover work to the policewoman's public persona and revealed a preoccupation with their sexuality that would also permeate the courtroom.

By the second decade of the twentieth century, undercover work emerged as a primary means of professional recognition for policewomen, leading to commendations, money, and promotions. By 1910, Isabella Goodwin was experienced in cases involving fortune tellers, spiritualists, false medical practitioners, and con artists. Despite her transfer to the detective bureau, she retained the "matron" title and salary. Her status changed in February 1912, when two bank clerks transporting $\$ 25,000$ between branches via taxi were robbed at gunpoint in an infamous

\footnotetext{
${ }^{18}$ Sullivan, My Double Life, 38, 140.

${ }^{19}$ On the transfer from surveillance of women's welfare to policing repertoire in England, see Louise Jackson, Women Police: Gender, Welfare and Surveillance in the Twentieth Century (Manchester, UK, 2006), 109.

${ }^{20}$ Female journalists also went undercover to investigate abortion in the late nineteenth century, such as Augustus St. Clair's "Evil of the Age" series for the New York Times in 1871 and the "girl reporter" of the "Infanticide" series for the Chicago Times in 1888-1889. See Appier, Policing Women, 24-9 and Sullivan, My Double Life, 57, 65, 88-9.

${ }^{21}$ Jackson, Women Police, 110-3.

22“Mrs. Goodwin's Love Lure Led to Prison," The Sun, Nov. 28, 1913, 2.

${ }^{23}$ Louise Jackson makes this observation about women's undercover work in 1950s Britain in Women Police, 114.

24“Detective's New Husband Is Her Own Secret Affair," The New York Herald, Nov. 28, 1921, 5.
} 
case known as the "taxicab robberies." The NYPD could not locate their main suspect, "Eddie the Boob" Kinsman, so they pursued his girlfriend "Swede Annie." To do so, the deputy commissioner looked to Isabella Goodwin. The matron donned a "shabby suit" and "old shoes" to seek employment in Annie's rented accommodation as a maid in order to gather evidence. ${ }^{25}$ Goodwin immersed herself in the role: she served three meals a day; "swept and scrubbed the floors"; and collected rent, all the while conducting policework by listening "through the key hole." ${ }^{26}$ When she learned that "Swede Annie" had some new clothing, she followed her hunch and telephoned the shop owners, discovering that the suit was purchased in Albany with the stolen dollar bills. Her information led to the arrest of the perpetrators and inspired national newspaper headlines, a special police commendation, and, at age forty-seven, Goodwin became the first female detective in the United States, earning a salary equal to male officers. As a detective, investigating abortion became one of her main duties.

\section{Undercover Abortion Investigations, 1913-1918}

Abortion was particularly visible in nineteenth-century New York City; it was the site of the cat and mouse chase between Madame Restell, the most infamous abortionist in United States history, and Anthony Comstock, the well-known leader of anti-vice campaigns. At the turn of the century, people traveled from all over the state and further afield to access abortion, while the daily press ran sensationalized accounts of abortion-related deaths. ${ }^{27}$ Although notorious, abortion seemed impossible to police. Medically, the presentation of spontaneous miscarriage and induced abortion were often indistinguishable. Practically, abortion occurred in physical spaces and social networks beyond regulators' reach. And legally, most eyewitness testimony entailed the complicity of a witness in the crime. While most women who had abortions in the criminal era survived, these regulatory challenges meant that the historical record disproportionately captured abortion-homicides. ${ }^{28}$ Informed by this, histories of abortion in the early twentieth century have focused on the regulation of "dangerous" practitioners who caused women's deaths. ${ }^{29}$ However, in New York City, there were significantly more arrests for abortion when a woman survived; the state was more interested in controlling abortion than previously thought (Figure 1).

In the early twentieth century, physicians' efforts to regulate abortion dovetailed with their desire to marginalize midwives in the competitive medical marketplace. For New York's immigrant communities, midwives played a vital medical and social role, as they shared a language with their patients, paid house visits, and spread information and gossip. As community insiders, their authority often outstripped that of physicians. ${ }^{30}$ Midwife services were also

\footnotetext{
25“Only Woman Detective Relates How She Captures," The Sun, Aug. 11, 1912, 8.

26“The First Municipal Detective in the World," New York Times, Mar. 3, 1912, 6.

${ }^{27}$ Beisel, Imperiled Innocents; Janet Farrell Brodie, Contraception and Abortion in Nineteenth-Century America (Ithaca, NY, 1994); Amy Gilman Srebnick, The Mysterious Death of Mary Rogers: Sex and Culture in Nineteenth-Century New York (New York, 1995); Cheree Carlson, The Crimes of Womanhood: Defining Femininity in a Court of Law (Urbana, IL, 2009), 111-35.

${ }^{28}$ On the myth of the "back-alley butcher," see Rickie Solinger, Beggars and Choosers: How the Politics of Choice Shapes Adoption, Abortion, and Welfare in the United States (New York, 2002), 37-42; and Carole Joffe's remarkable work on the decades before Roe, "Portraits of Three 'Physicians of Conscience': Abortion before Legalization in the United States," Journal of the History of Sexuality 2, no. 1 (1991): 46-67.

${ }^{29}$ Looking at coroner records, Leslie Reagan argued, "From the late nineteenth century through the 1930s, the state prosecuted abortionists primarily after a woman died." Leslie Reagan, "About to Meet Her Maker: Women, Doctors, Dying Declarations, and the State's Investigation of Abortion, Chicago, 1867-1940," Journal of American History 77, no. 4 (Mar. 1991): 1247-64.

${ }^{30}$ Reagan, "Linking Midwives and Abortion in the Progressive Era"; Elizabeth Ewen, Immigrant Women in the Land of Dollars: Life and Culture on the Lower East Side, 1890-1925 (New York, 1985), 131-2.
} 


\section{Number and Type of NYPD Abortion Arrests per annum}

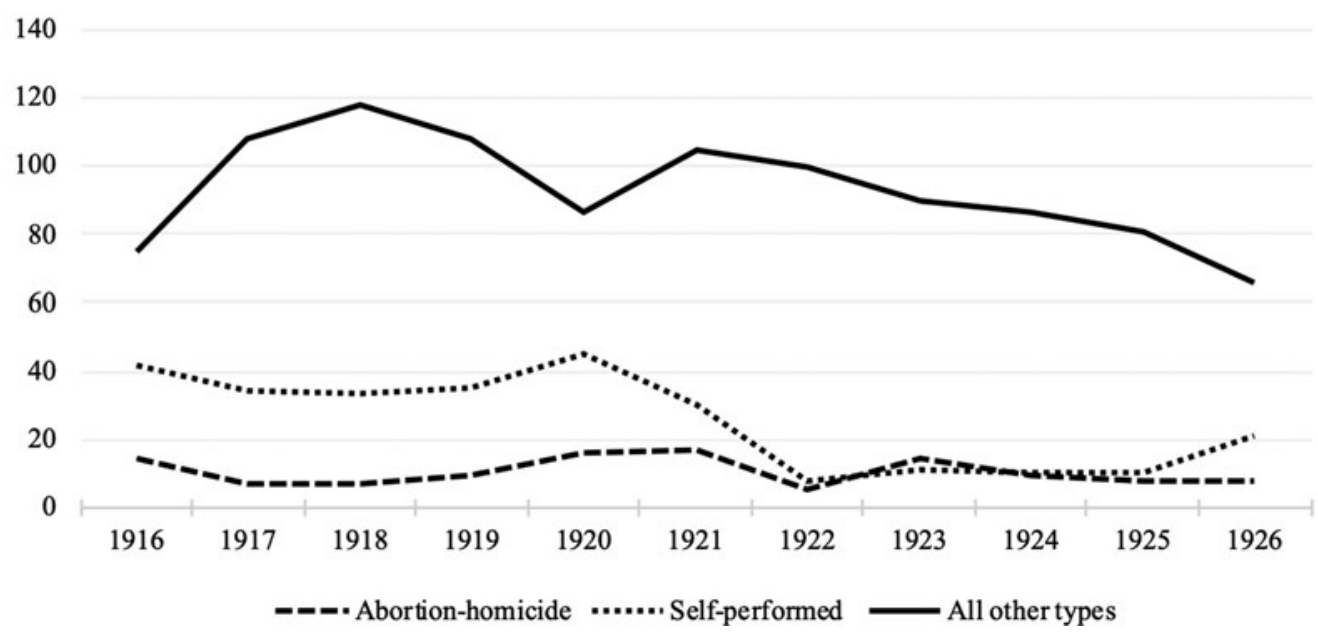

Figure 1. Data from NYPD annual reports 1916-1926 on the type of abortion offense. "All other types" includes abortions arrests listed as "unclassified," "attempted," "committed on patient by female," "committed on patient by male," and "committed on other persons."

economical, as they charged less money than physicians and tended to both mother and infant. ${ }^{31}$ State and private organizations subjected midwives to greater surveillance, as the particular embodiment of nativist fears. Midwives represented immigrant women's networks of exchange and autodidactic knowledge production that did not conform to the increasingly exclusive definitions of medical authority. This led professionals to brand midwives "dangerous." As nurse and leader of the settlement house movement, Lilian Wald summarized: "Perhaps nothing indicates more impressively [the medical establishment's] contempt for alien customs than the general attitude taken toward the midwife." 32

"The two terms 'midwife' and 'abortionist' are synonymous," argued Elisabeth Crowell in a 1907 article for Charities and Commons, blaming midwives for the majority of the estimated 100,000 abortions committed annually in the city. In 1906, Crowell, a nurse by trade, posed as a Board of Health inspector to investigate over 500 midwives in immigrant neighborhoods on Manhattan's Upper and Lower East Side. Her report led to the 1907 Midwifery Law that empowered the Board of Health to issue and demand licenses, annual registration, and inspections of literacy, cleanliness, and equipment. ${ }^{33}$ Private reform groups responded to this mandate with greater surveillance of midwives. In 1909, Ruth Standish Baldwin of the Committee of Fourteen investigated twenty-seven midwives who advertised in foreign-language newspapers, finding that twenty-three agreed to perform an abortion. Baldwin described one midwife's office as "indescribably dirty" with a "foul odor," and the midwife herself as intoxicated, telling "revolting stories," including "relieving young girls" through abortion. ${ }^{34}$ Baldwin's description drew upon white slavery narratives of a young female victim, a vision

\footnotetext{
${ }^{31}$ Judy Barrett Litoff, "Forgotten Women: American Midwives at the Turn of the Twentieth Century," The Historian 40, no. 2 (Feb. 1978): 235-51.

${ }^{32}$ Lilian Wald, The House on Henry Street (New York, 1938), 57-8.

${ }^{33}$ Elizabeth Crowell, "The Midwives of New York," in The American Midwife Debate: A Sourcebook on Its Modern Origins, ed. Judy Barrett Litoff (New York, 1986), 39-40, 45. See also Reagan, "Linking Midwives and Abortion in the Progressive Era"; and Joyce Thompson and Helen Varney Burst, A History of Midwifery in the United States: The Midwife Said Fear Not (New York, 2016), 38.

${ }^{34}$ Research Committee of the Committee of Fourteen, The Social Evil in New York City: A Study of Law Enforcement (New York, 1910), 101-11, 106.
} 
central to the Committee's work, but she cast the midwife, rather than a male seducer, as the predator. White slavery narratives deployed xenophobia and antisemitism to paint an image of foreign villains "who despoiled the purity of a young, white, Christian victim and lived off the proceeds of her shame," as historian Val Marie Johnson described. ${ }^{35}$ The Committee's inspector mapped these tropes onto the midwife to justify the "constant and painstaking supervision" and heralded women's special role in this regulation. ${ }^{36}$

Under the leadership of Lieutenant Dan Costigan, NYPD Special Squad Number Two performed a range of undercover vice investigations, but between 1913 and 1918 their main investigative duty was policing abortion. Policewomen had previously partnered with private medical interests to defend the boundaries of professionalism, with Isabella Goodwin working with a female detective of the New York County Medical Society to gain evidence against irregular practitioners. ${ }^{37}$ This new squad extended these shared interests and consisted of two teams of two women: Ada Brady and Maude Leslie, and Isabella Goodwin and Adele Priess. Goodwin was a working-class New Yorker, while Brady was a first-generation Irish immigrant. ${ }^{38}$ Matron Adele Priess, who worked as a translator on investigations with Goodwin, was born in New York to parents from Alsace on the French-German border. She learned German "through having heard it spoken at home" and worked as a language teacher before her marriage to a German migrant. ${ }^{39}$ Special Squad Two assembled a team of ambitious, experienced matrons, whose class and immigration status reflected the communities they sought to police.

In a precedent-setting January 1913 case, Isabella Goodwin and Adele Priess visited a midwife's office at 333 East 79th Street, in the immigrant populated Yorkville neighborhood on Manhattan's Upper East Side. Matron Priess had a muddled conversation in German with midwife Pauline Papp, who would have preferred to use Hungarian. In their polyglot discussion, Priess explained that Goodwin missed menstruation, suffered morning sickness, and feared she was pregnant. They needed to end the pregnancy because she "was a widow, she works in an office, and her friend is a married man." Midwife Papp declined to give medicine and recommended instead that she undertake a pelvic examination, citing her twenty-three years of midwifery experience and training in Budapest. But Goodwin hesitated. Papp suggested that she go home instead, take a hot English mustard bath, wrap up warm, and return in the morning if these measures did not induce an abortion.

When the policewomen returned to Papp's office the next day, she agreed to perform an operation for twenty-five dollars. When the pair tried to haggle, she explained that while they may find someone that charged less, she knew how to do it "well and right." The women agreed and Goodwin lay on her back on the cold dining room table. She drew her knees up, placing her feet flat on the wooden surface, and lifted her skirts in preparation for the intimate exam. She felt the midwife's fingers inside her and saw her reach for surgical instruments. Papp positioned a syringe at the entrance to detective Goodwin's vagina. At this moment, the policewoman announced she felt sick with nerves and her partner ran to the window, where she drew a handkerchief to her face. Two male officers waiting on the street recognized this gesture as a signal and entered the apartment. They arrested the midwife, who protested in English that "all midwives fix.".

\footnotetext{
${ }^{35}$ Johnson, "Protection, Virtue, and the 'Power to Detain," 662.

${ }^{36}$ Committee of Fourteen, The Social Evil in New York City, 110.

${ }^{37}$ See Elizabeth Evens, “The Most Doctored Woman in New York': Medical Professionalism and Surveillance in the Career of Detective Frances Benzecry," Society for Historians of the Gilded Age and Progressive Era Blog, Oct. 14, 2019, https://www.shgape.org/the-most-doctored-woman-in-new-york-medical-professionalism-and-surveillancein-the-career-of-detective-frances-benzecry/ (accessed Jan 8, 2020).

${ }^{38}$ Ada Brady also occasionally worked with a nurse, Helen Callogran.

${ }^{39}$ People v. Pauline Papp, Jan. 10, 1919, p. 7, trial 1760, reel 318, New York Court of General Sessions, Criminal Trial Transcripts Collection, New York Lloyd Sealy Library [hereafter NYCGS].

${ }^{40}$ People v. Papp, 7.
} 
Goodwin and Priess recounted these events on the witness stand in the court of general sessions, where the case created new precedent: a woman did not have to be pregnant for the defendant to be guilty of an attempted abortion. ${ }^{41}$ Judge J. McLaughlin dissented and argued that Papp's case ought to be dismissed as "had the defendant succeeded in doing all that she intended to do she would not have committed the crime of abortion." ${ }^{\prime 2}$ Although this complaint haunted the method, the NYPD deployed it as the primary means of policing abortion. The New York district attorney recorded twenty Special Squad Two cases against twenty-five defendants, but most investigations did not lead to indictments and Isabella Goodwin alone recalled working on forty such cases. ${ }^{43}$

Women were uniquely capable of carrying out these investigations, and not only because their bodies could meet the evidentiary bar, but also because female relationships linked each stage of criminal abortion: sourcing an abortionist, attending the procedure, aiding recovery, and offering compassion. ${ }^{44}$ Because of the homosocial nature of abortion, women could, and did, seek a special role policing the crime by disrupting the physical and social spaces that eluded their male colleagues. ${ }^{45}$

The disguises policewomen adopted indicated which practitioners and patients they sought to control. When abortion was criminalized in the nineteenth century, physicians and feminists alike argued that genteel white women most frequently sought abortions. Against the backdrop of high immigration rates from Ireland, and from eastern and southern Europe, this rhetoric evoked the nativist specter of "race suicide." This image of the white upper class aborting woman endured into the early-twentieth century, most patently in the 1916 film Where Are My Children?, written and directed by Lois Weber for Universal Pictures. ${ }^{46}$ However, in practice, regulatory efforts did not focus on Manhattan's affluent white doctors and their clientele. Rather, municipal policewomen targeted the immigrant neighborhoods of Yorkville, East Harlem, and the Lower East Side. ${ }^{47}$ They posed as working-class immigrant mothers using language skills and adopting accents. The NYPD co-opted and then weaponized the class and gender community that matrons shared with those they policed in order to destabilize and dismantle the networks upon which criminal abortion depended. In some plainclothes

\footnotetext{
${ }^{41}$ People v. Papp, 165. Cited in contemporary legal handbooks, for instance, Arthur B. Spingarn, Laws Relating to Sex Morality in New York City (New York, 1915), 6.

${ }^{42}$ Judgment included in case 111963, folder 70, box 1306, NYMA, DA.

${ }^{43}$ Case numbers relate to Special Squad Two cases between 1916 and 1918. People v. Bertha Schmulenson, Jan. 10,1919 , p. 16, case 2551, reel 318, NYCGS.

${ }^{44}$ On female networks of exchange in the pre-industrial era, see Linda Gordon, Woman's Body, Woman's Right: A Social History of Birth Control in America (New York, 1976), 26-9; Leslie Reagan, When Abortion Was a Crime: Women, Medicine, and Law in the United States, 1867-1973 (Berkeley, CA, 1997), 30-1.

${ }^{45}$ Harris, "Women and Girls in Jeopardy"; Stephen Robertson, "Harlem Undercover: Vice Investigators, Race, and Prostitution, 1910-1930," Journal of Urban History 35, no. 4 (May 2009): 486-504.

${ }^{46}$ Nicola Beisel and Tamara Kay, "Abortion, Race, and Gender in Nineteenth-Century America," American Sociological Review 69, no. 4 (Aug. 2004): 498-518; Where Are My Children?, directed by Lois Weber and Phillips Smalley (Universal, 1916).

${ }^{47}$ The New York District Attorney Indictments record that the NYPD arrested 34 individuals following policewomen's undercover investigations between 1916 and 1925. Those arrestedlived at 28 separate addresses; eleven in Yorkville, eight in the Lower East Side, six in Harlem, two in Midtown, and one on the West Side. Yorkville, bound by 72 nd Street to the south and 96th Street on the north, Central Park, and the East River, was home to Irish, German, Hungarian, Czech, Slovakian, and Italian immigrants. The Lower East Side was home to groups of immigrants, particularly following waves of Italian, Jewish, and Eastern European migration from the 1880s. At the turn of the century, Irish and Jewish populations began to leave East Harlem, and by the 1920s a large part was an Italian community, as Robert Orsi detailed in his study of religion in this area. See "Yorkville" and "Lower East Side" in Kenneth Jackson, Lisa Keller, and Nancy Flood, eds., The Encyclopedia of New York City (New Haven, CT, 2010), 1428; Lawrence Epstein, At the Edge of a Dream: The Story of Jewish Immigrants on New York's Lower East Side 1880-1920 (San Francisco, 2007); Robert Orsi, The Madonna of 115th Street: Faith and Community in Italian Harlem, 1880-1950 (New Haven, CT, 2010), 16-23.
} 
investigations, white policewomen investigated Black spiritualists and medical practitioners-as Mary Sullivan documented in her autobiography-but there are no records of white policewomen targeting Black midwives in their abortion investigations. ${ }^{48}$

Policewomen constructed narratives of reproductive vulnerability to create believable disguises. Their stories were reminiscent of the real women who wrote letters to birth control advocate and eugenicist Margaret Sanger's journal, the Birth Control Review, asking for abortion information. In a December 1917 letter, "Mrs L S" was seventeen years old, had two infant children under the age of two, and suspected she was pregnant again. She wrote to the Review of her health problems, her pain, her difficulty breastfeeding, and that she weighed just ninetysix pounds. The teenager confided that if her husband discovered her pregnancy he would "beat the life out of" her and she would "give or do anything not to have another baby." She was "entirely at [their] mercy." familial, and health reasons for seeking an abortion. In May 1918, she detailed the expenses for her husband, child aged ten months, and disabled parents-in-law: her husband's wage was $\$ 18$, they paid $\$ 6$ rent, $\$ 1.50$ for milk, $\$ .50$ for baby food, and $\$ 3.50$ for their own meager diet of dry vegetables, bread, and coffee. ${ }^{50}$ In investigations, policewomen imitated these narratives by wearing black to pose as widows, asking for a reduced fee, and emphasizing the number of children they had in order to nurture a false and misleading community with the midwives.

Policewomen's evocations of aborting women were not always convincing however. In her autobiography, Margaret Sanger recalled a police raid of her recently opened Brownsville clinic in October 1916. Brooklyn detective Margaret Whitehurst visited the clinic and claimed to be a penniless mother of two, but staff remained skeptical as she did not appear "overburdened or anxious" and was "well fed as to body and prosperous to clothes." Most conspicuously, Whitehurst insisted on paying two dollars for the ten-cent copy of Sanger's writings. When she left, Sanger allegedly pinned the two-dollar bill to the wall with the caption "Received from Mrs. - of the Police Department, as her contribution." ${ }^{51}$ She gave a scathing description of Whitehurst to the Brooklyn Daily Eagle following her arrest, stating that perhaps the woman detective "did only her duty," but Sanger would "rather scrub floors for [her] bread than earn it by fighting [her] sisters." 52

Even when confronted with policewomen's direct testimony and, frequently, reliance on language interpreters to understand proceedings, midwives protested the criminalization of their behavior. They organized in protective associations to furnish legal aid when members faced abortion charges and attended trials to study the faces of female investigators. ${ }^{53}$ In March 1917, policewoman Ada Brady accused sixty-nine-year-old German midwife Elizabeth Bayer of attempted abortion following an undercover investigation. Bayer wrote to the district attorney asking to appear before the grand jury and "tell them my story" of a "perfect record" maintained over thirty-three years practicing midwifery. It is unclear whether Bayer did appear in court, but the case against her was dismissed. Her letter showed how a working class, immigrant woman-usually seen as the subject of social control-harnessed the legal system to contest her treatment. ${ }^{54}$ In trials, midwives employed defense attorneys with whom they shared a nationality and culture. Together they drew attention to language barriers between police and midwives, questioned policewomen's accounts, and undermined their methods.

\footnotetext{
${ }^{48}$ Sullivan, My Double Life, 147-51.

${ }^{49}$ Mrs L S, "Letter no. 1," Dec. 11, 1917, The Birth Control Review 2, no. 1 (Jan. 1918): 13.

${ }^{50}$ Mrs C B, “Letter no. 14," undated, The Birth Control Review 2, no. 4 (May 1918): 12.

${ }^{51}$ Margaret Sanger, Margaret Sanger: An Autobiography (New York, 1938), 219-20.

52"Mrs. Sanger, After Night in Jail, Has New Worries," Brooklyn Daily Eagle, Oct. 27, 1916, 22.

${ }^{53}$ Crowell, The Midwives of New York, 45; Committee of Fourteen, The Social Evil in New York City, 110.

${ }^{54}$ Letter from Elizabeth Bayer to Edward Swann, Mar. 23, 1917, case 114481, folder 256, box 1333, NYMA, DA; Donovan and Barnes-Brus, "Narratives of Sexual Consent and Coercion," 616.
} 
Midwives also exploited policewomen's professional precarity to discredit their testimony. When asked why she performed a pelvic exam on detective Isabella Goodwin, Pauline Papp alleged that she "was positive that [Goodwin] was not pregnant," but "that she was syphilitic." In another case, Russian Jewish midwife Bertha Schmulenson argued that she examined the policewoman as "her stomach was very fat." ${ }^{\text {" }}$ Midwives impugned policewomen's respectability as a form of resistance that highlighted the gendered tensions between women and their female regulators. The tension could stifle abortion investigations. Policewoman Mary Sullivan claimed that when policewomen tried to arrest female midwives, they would "fling their instruments out the window, tear their hair, and beat their heads against the wall," whereas a male arrestee hesitated to "make himself ridiculous by struggling against a feminine police officer" and instead "sheepishly" accompanied them to the precinct. ${ }^{57}$ In abortion trials, policewomen's gendered precarity became a resource for midwives to protest their criminalization.

Abortion investigations were a thus a paradox for policewomen. On one hand, these cases led to career advancement; Isabella Goodwin and Adele Priess received a merit on the honor roll because of their arrest of an abortionist. ${ }^{58}$ Yet, despite representing the state and serving as gatekeepers of feminine respectability, the investigative method demanded that Special Squad Two behave disreputably. In the masculine courtroom, policewomen's bodies were key evidence, and attorneys scrutinized their moral character by asking about their marital status, husband's job, and number of children they had. Despite the ruling that a woman did not need to be pregnant for an abortion attempt, the manner of the insertion of hands and instruments into female officers' vaginas emerged as a key moment as the court grappled to establish intent. Prosecutors' and defense attorneys' questions echoed the titillating newspaper accounts of female sleuths. ${ }^{59}$

Undercover abortion investigations resulted in comparatively few indictments and convictions. But despite limited prison sentences, these cases punished midwives by printing their names in newspapers and confiscating medical equipment. ${ }^{60}$ More importantly, this plainclothes work destabilized the female networks central to the practice of abortion during the criminal era, the effects of which cannot be measured by counting affidavits. When policewomen gained an ally in the first female NYPD deputy police commissioner in 1918, their discomfort with the investigative process, as well as the limited number of convictions secured, led to the suspension of undercover abortion investigations.

\section{Female Management and the Changing Surveillance of Women's Sexuality}

In January 1918, Ellen O'Grady became fifth deputy commissioner of the New York Police Department, the first woman to hold that rank. O'Grady was an Irish immigrant, widowed mother to three daughters, and a Brooklyn probation officer of ten years. Writer Djuna Barnes commented on O'Grady's commanding presence, writing that she possessed a mouth that "moves for the state." ${ }^{61}$ Incoming mayor John Hylan appointed her in response to the

\footnotetext{
${ }^{55}$ People v. Pauline Papp, 115.

${ }^{56}$ People v. Bertha Schmulenson, 66, 68.

${ }^{57}$ Ibid., 155.

58“"Women Detectives Honored," New York Tribune, Feb. 23, 1916, 10.

${ }^{59}$ Brian Donovan analyzed Progressive Era trials and showed how defense attorneys questioned the sexual respectability of female witnesses in White Slave Crusades: Race, Gender, and Anti-Vice Activism, 1887-1917 (Urbana, IL, 2006), 101-3.

${ }^{60}$ LaShawn Harris described how newspapers maligned supernatural workers, who were also targets of plainclothes female officers, in Sex Workers, Psychics, and Numbers Runners: Black Women in New York City's Underground Economy (Urbana, IL, 2016), 120.

61"Women Police Deputy in Office," New York Tribune, Jan. 30, 1918, 9; Djuna Barnes, "Woman Police Deputy Is Writer of Poetry," in Vivid and Repulsive as the Truth: The Early Works of Djuna Barnes, ed. Katharine Maller (New York, 2016), 110.
} 
shifting policing concerns of World War I and the expansion of voting rights to women. ${ }^{62}$ With the United States' entry to the war, the regulation of female sexuality assumed a new importance as a paramount issue of national defense and keeping soldiers "fit to fight." This changed the status of the policewoman in New York and nationally. In 1917, the federal government formed the Commission of Training Camp Activities (CTCA) that, empowered by the Chamberlain-Kahn Act, aimed to halt the spread of venereal disease by subjecting "suspicious looking" women to involuntary medical examinations, imprisonment, and possible long-term confinement to a reformatory or detention center. While some female reformers led criticisms of this program, other women engineered this regulation. In many cities, these wartime powers were a catalyst for the introduction of women in policing for the first time, as the CTCA recruited a new cadre of middle class volunteers as "patrolwomen" to regulate wartime sexual and social behavior. Meanwhile in New York City, the war added personnel and duties to a movement well versed in the regulation of female sexuality. ${ }^{63}$

Ellen O'Grady hired six patrolwomen from the milieu of college educated, volunteer, or politically affiliated women, distinct from the earlier generation of matrons. Meanwhile, in May 1919, commissioner Richard Enright bypassed the civil service exam to appoint New York's first African American, Italian, and Jewish policewomen-Cora Parchment, Rae Nicoletti, and Rose Goldstein — tasked with surveilling neighborhoods of their ethnic and racial backgrounds. ${ }^{64}$

O'Grady also created a new "social welfare" squad under her direct supervision in February 1918, recruiting Isabella Goodwin, Adele Priess, Maude Leslie, and Ada Brady, the four policewomen who previously comprised the abortion squad. ${ }^{65}$ In the 1918 NYPD annual report, O'Grady denounced the former method of policing the "horrible crime" of abortion:

The Fifth Deputy Commissioner did away with the old custom that compelled a female representative of the Police Department to submit herself to a physical examination in order to gain evidence against abortionists. The manner of getting evidence now is less dangerous and not so degrading. The old method was useless, no convictions being possible as the female representing the Police Department was forced to voluntarily participate in the commission of a crime, and became, consequently, an accessory. The wonder is that nobody saw the worthlessness of the practice before. ${ }^{66}$

When a woman ascended to NYPD leadership, she took steps to guard the female officers in her employ. Social mobility, longevity in policing, and a powerful ally amplified veteran policewomen's voices, leading to improved working conditions and mitigating their courtroom humiliation. However, these professional women's empowerment continued to come at the expense of other women. Despite O'Grady's disavowal, undercover abortion investigations continued in a modified form. Instead of policewomen's bodies, the NYPD now placed young working-class women, who had previously had an abortion, on the line.

\footnotetext{
62"Woman Named as Police Deputy in New York," The Hartford Courant, Jan. 29, 1918, 1.

${ }^{63}$ Scott Stern, The Trials of Nina McCall: Sex, Surveillance, and the Decades-Long Government Plan to Imprison "Promiscuous" Women (Boston, 2018), 69; Odem, Delinquent Daughters, 121-7; Schulz, "A Precinct of Their Own," 42, 44-5; Courtney Shah, "Against Their Own Weakness': Policing Sexuality and Women in San Antonio, Texas, during World War I," Journal of the History of Sexuality 19, no. 3 (Sep. 2010): 458-82.

${ }^{64}$ Indeed, the titles "patrolwomen" and "policewomen" were only merged in 1937. "Six Policewomen Put on the Force," New York Times, Aug. 16, 1918; Schulz, "Precinct of Their Own,” 43. Parchmont resigned just months later and was replaced by Lawon Bruce, the second Black woman on the NYPD. See Aldrich-Moodie, "Staking Out Their Domain," 197-8.

65“Enright Overrules Woods Decision in New Shake-Up," New York Tribune, Feb. 14, 1918, 8.

${ }^{66}$ NYPD, “Annual Report” (New York, 1918), 89.
} 
Policewomen experimented with alternative methods of abortion control before O'Grady's appointment. In May 1917, matron Ada Brady went undercover to gather evidence against German midwife Augusta Peters for performing an abortion. In this case, instead of prosecuting Peters, the NYPD recruited her as an informant. ${ }^{67}$ Thus when twenty-two-year-old Finnish Iraka Monthan visited Peters two months later, the midwife instructed her to return to an abortionist who had ended her pregnancy before. Peters then informed the NYPD who sent detective Isabella Goodwin to pursue Monthan to the office of German midwife Lena Motz, but Goodwin arrived too late to stop Motz inserting a firm rubber bougie in Monthan's vagina. ${ }^{68}$ Iraka Monthan did not miscarry until weeks later, at which time she was incarcerated in the Waverly House detention center. Goodwin coerced Monthan into complying with the prosecution, allegedly telling her "that if [she] didn't tell that story to the Harlem Police Court [she] will get in prison for five years." ${ }^{69}$ When Monthan took to the stand, she endured questions about her sexual history, the circumstances of the abortion, and her knowledge of policewomen's involvement, all the while feeling the experienced eyes of the detective upon her. As the assistant district attorney commented in the trial, the young woman had become the inadvertent "stool pigeon." found ways to punish them beyond obtaining a conviction. ${ }^{71}$

In 1919, policewomen again coerced a pregnant woman into supplying evidence in an abortion trial. ${ }^{72}$ Two policewomen approached twenty-eight-year-old and pregnant Anna Colwell and instructed her to return to a male doctor who had previously performed an abortion for her. The policewomen accompanied her to the office, where Colwell received a pelvic examination. When the case went to trial in 1921, Colwell, instead of the policewoman, endured belligerent questioning. ${ }^{73}$ Attorneys told her that she had committed a crime, read her the law, warned her of the potential penalty, and asked her in detail about the attempted procedure. ${ }^{74}$ Colwell expressed her discomfort on the stand and complained that the investigation had continued for over two years, during which time she had "lost two positions," had to take care of "a sick baby," and "was ashamed of everything."75 Policewomen had decisively shifted the burden of the demeaning investigative process.

Meanwhile, Ellen O'Grady adopted a casework approach that commenced new types of surveillance. In 1918, Anna Vogel wrote to mayor John Hylan's office-a common tactic for citizens seeking redress-as she had gotten pregnant from an extramarital affair while her husband served abroad, and sought help. O'Grady visited her on several occasions and oversaw her move to a maternity home. Her case report conveyed frustration with Vogel, whom she chastised for wearing corsets that were too tight in an effort "to conceal her condition," causing the baby to be underweight. But what irked the deputy commissioner most was that when Vogel's husband, "who she deceived," returned, Vogel would have given the infant to the sisters

\footnotetext{
${ }^{67}$ Ada Brady v. Augusta Peters, Mar. 30, 1917, case 114755, folder 275, box 1336, NYMA, DA. Augusta Peters's lawyer Samuel Dickheiser later defended midwife Lena Motz, who Peters had implicated. He raised this issue in the trial People v. Lena Motz, 1919, p. 82, trial 2557, reel 319, NYCGS.

${ }^{68}$ Monthan had initially avoided returning to Lena Motz because she was gravely ill following the first procedure. Waverly house case 4550 , July 12,1917 , case 116770 , folder 449 , box 1363 , NYMA, DA. This bougie remains in the DA Indictment folder to this day.

${ }^{69}$ People v. Lena Motz, 117.

${ }^{70}$ Ibid., 64.

${ }^{71}$ The district attorney declared "the ends of justice do not require us to proceed against" women who had abortions, John F. O’Neil, “Memo for Mr Ryttenberg,” Jan. 7, 1920, case 119041, folder 666, box 1389, NYMA, DA; Reagan, "About to Meet Her Maker," 1243.

${ }^{72}$ People v. Frederick Van Vliet, Jan. 18, 1919, case 123653, folder 3982, box 1728, NYMA, DA; People v. Frederick Van Vliet, Dec. 1919, case 127572, folder 1417, box 1474, NYMA, DA.

${ }^{73}$ People v. Frederick Van Vliet, Aug. 9, 1921, p. 53-74, trial 3031, reel 365, NYCGS.

${ }^{74}$ Ibid., $18-30$.

${ }^{75}$ Ibid., 32.
} 
at the New York Foundling Asylum, thus bearing no consequences for her transgressions. ${ }^{76}$ Policewomen maintained their position as gatekeepers of reproductive surveillance.

Notably, O'Grady exercised only limited authority within the male-dominated world of the NYPD. If she protested institutional misogyny, she undermined her own position. Two cases illustrate both O'Grady's agency, but also her circumscribed approach, to sexual assault. On December 2, 1919, O'Grady received complaints that two wealthy, influential men had sexually assaulted two seventeen-year-old girls. She sent Adele Priess to arrest them, but police commissioner Richard Enright's staff secretary blocked the matron. O'Grady wrote to Enright on December 26: "It is high time that millionaires like Seaman and Dempsey [the accused rapists] are punished for taking pretty children into their apartment for immoral purposes." The Commissioner could not "deter [her] in the performance of [her] duty."77

Another allegation of sexual assault had passed O'Grady's desk in April 1918, in which a prison matron complained that a male guard sexually assaulted female inmates as he escorted them alone through a passage from the jail to a van that took them to court. O'Grady judged the case to be false because the female witnesses had "prison records," and a victim allegedly lied frequently, according to her probation officer. Instead, O'Grady attributed the claim to a personality clash between the matron and the guard. This case was not reported in newspapers, and O'Grady never compared it to her 1919 protests, but her judgment of the accusers in this case echoed her report on pregnant Anna Vogel and treatment of the "stool pigeons" in abortion investigations, whose own criminality was implicated in their cases. In O'Grady's eyes, perhaps, these cases did not conform to the standards of perfect victimhood exemplified in the teenagers reportedly assaulted by the millionaires Seaman and Dempsey. ${ }^{78}$

When O'Grady sought to prosecute the two wealthy men in December 1919, commissioner Enright marginalized her within the department, by diverting her staff to other duties and no longer supporting any of her initiatives. Her outspoken critique had come at a price. One year later, O'Grady marched into Enright's office and threw her badge on the desk, announcing: "I could not stay and retain my self-respect and independence. I was forced to resign. There was nothing else I could do."79

\section{Expanding Undercover Techniques and Surveilling Queer Women}

O'Grady's resignation was followed by another setback for the policewoman's cause. In early 1921, the NYPD established an experimental Women's Precinct that, despite a well-publicized opening, soon fell into obscurity and quietly closed in September 1923 with no official reason. ${ }^{80}$ These two events placed women in New York policing in complex dialogue with the nascent national policewomen movement. Established in 1915, the International Association of Women Police (IAWP) grew with the wartime and postbellum expansion of policewomen to new cities. The IAWP pursued professionalization through a monthly bulletin that detailed information about affluent donors, instructions to lobby state legislatures, and even reading lists to learn more about the movement. It promoted a vision of the modern policewoman that stressed education-ideally at the college level—and formal training according to the ideals of "prevention and protection."

\footnotetext{
${ }^{76}$ Ellen O'Grady to Marian Hylan, Dec. 18, 1918, roll 139, Departmental Correspondence: Police Department, New York Municipal Archives Mayor Hylan Papers [hereafter NYMAHP]. Also cited in Aldrich-Moodie, "Staking Out Their Domain," 180-1.

${ }^{77}$ Ellen O’Grady to Richard Enright, Dec. 26, 1919, roll 141, NYMAHP.

${ }^{78}$ Chas I Stengle to Mayor Hylan, Apr. 1, 1918; Ellen O’Grady to Chas I. Stengle, Apr. 6, 1918; Ellen O’Grady Case Report, Apr. 13, 1918, roll 139, Departmental Correspondence: Police Department, NYMAHP.

79“Mrs O'Grady, Hurling Shield at Enright, Quits; Assails Commissioner," New York Tribune, Dec. 14, $1920,1$.

${ }^{80}$ Historian Dorothy Schulz has argued that its closure stemmed from the precinct's aim to house women who had not committed a crime, which encroached upon the established charity sector and conflicted with the concurrent push to professionalize social work. See Schulz, "Precinct of Their Own," 59-65.
} 
In New York, despite the appointment of some middle class women after World War I, in 1920, of seventy-five policewomen officially employed by the NYPD, fifty-five were former matrons, including Mary Sullivan. ${ }^{81}$ However, like O'Grady, Sullivan endured a backlash when challenging NYPD priorities. "The story of my eclipse began in 1918," she wrote in her autobiography, when she petitioned the state legislature to change the status of the "matron," who were "paid less than the patrolmen, had no opportunities for promotion, and were given very low pensions" comparatively. In May 1920, Sullivan's complaint achieved legislative assent and matrons became "policewomen," but Sullivan also earned a reputation as a troublemaker. Because she had "stepped out of [her] place," when all NYPD women were reassigned following the fleeting women's precinct, Sullivan found herself consigned to a stationhouse. For Sullivan, "to be sent back to matron duty after having served on the Homicide Squad and worked on important cases for the district attorney's officer was a stunning blow." ${ }^{\prime 2}$

Meanwhile, the NYPD established a new twelfth division plainclothes squad, composed of "entirely fresh personnel." Amongst this squad were Barbara Popkin and Margaret Taylor, who recommenced undercover abortion investigations using the pelvic exam method. According to a 1924 annual report, they were "highly successful" in this practice. ${ }^{83}$ Policewomen extended undercover methods to police different crimes. New recruit Margaret Leonard, for example, surveilled the streets in plainclothes to gain evidence against "mashers"-men who verbally or physically harassed women on the street. ${ }^{84}$ Policewomen also expanded their expertise in matters of criminalized female sexuality in a landmark case involving a lesbian tearoom operator, which saw Margaret Leonard team up with Mary Sullivan, who returned to her investigative duties following the appointment of a new police commissioner.

Much like the women of the midwife's office, queer women occupied liminal social venues and urban spaces that male members of the NYPD could not easily access. Once more, policewomen pioneered investigative methods to extend state surveillance. In June 1926, the veteran Sullivan and rookie Leonard partnered to use undercover methods to investigate a Greenwich Village tearoom, "a "hangout-where ladies prefer each other," on the ground floor of 129 MacDougal Street. Sullivan published an account of the case in the October 1926 IAWP bulletin, describing it as typical of the "careful vigilance and observation" exercised by policewomen and the "drastic measures" taken to "clean New York of vicious moral perverts." ${ }^{\prime \prime}$ The case was so significant that Sullivan repeated it at length in her 1938 autobiography, citing the raid as an innovative example of policework for readers' information and entertainment.

Following a complaint to the district attorney, Sullivan and Leonard investigated the proprietress of the tearoom, Eve Adams, a Polish Jewish émigré, born Chawa Zloczewer, with a background similar to the midwives. ${ }^{86}$ Historians have detailed how state and private actors policed sexual acts between men in the early twentieth century, often arguing that male sexuality was more visible to authorities. The 1903 Ariston Bath Raids and 1917 Newport naval investigation

\footnotetext{
${ }^{81}$ Theresa Melchionne, "Policewomen: Their Introduction into the Police Department of the City of New York" (M.A. diss., Hunter College, 1962), 108-9.

${ }^{82}$ Sullivan, My Double Life, 142-3; "Police Women Win Same Rank and Pay as Men," New York Tribune, May 13, 1920, 13 .

${ }^{83}$ Unfortunately, due to damage from damp, only the affidavit in these cases remains. Margaret Taylor v. Philip Korn, Oct. 11, 1924, case 157217, folder 4242, box 1748; Barbara Popken v. Jane Adler, Oct. 8, 1924, case 157596, folder 4287, box 1754; Barbara Popken v. Pietrina Gennare, June 12, 1925, case 160534, folder 4601, box 1795; Barbara Popken v. Augistina Zumlauska, Aug. 27, 1925, case 160726, folder 4619, box 1797; Barbara Popken v. Margaret Reid, Jul. 31, 1925, case 161372, folder 4687, box 1806, NYMA, DA; NYPD, "Annual Report," 1924, 37, 101.

84"Pincher Pinches a Knee; Pinched by His Pinchee!” Daily News, Dec. 16, 1927, 198.

${ }^{85}$ Mary Sullivan, “The Tea Room Case," IAWP Bulletin, Oct. 1926, 5-6.

${ }^{86}$ On policing queer male immigrant bodies, see Nayan Shah, Stranger Intimacy: Contesting Race, Sexuality, and the Law in the North American West (Berkley, CA, 2011), 150-2.
} 
even harnessed plainclothes techniques. ${ }^{87}$ Meanwhile, histories of queer women have focused on carceral institutions as sites where female same sex desire was expressed, identified, and repressed. ${ }^{88}$ Yet, in the 1920 s, queer women also became more visible in urban centers, because of changing patterns of female marital practices and employment. ${ }^{89}$ These two policing trends coalesced in the tearoom case.

When Leonard and Sullivan visited the tearoom, they sat separately in the "artsy" venue, adorned with dark wooden beams, pewter, and "andirons that might have dated from the American Revolution." In her account, Sullivan painted Eve Adams as the sexual aggressor, a "wild looking individual," who approached Leonard "with the directness of a stone from a slingshot." Adams did not conform to feminine codes of dress or styling; in Sullivan's words, she had "cropped hair that was combed back in a ragged pompadour, and a mannish suit supplemented with a collar and tie." Indeed, her adopted name was a nod to the gender nonconformity she embodied. ${ }^{90}$ Mary Sullivan suffused her account with homophobic stereotypes characterizing Adams as possessing unrestrained, masculine sexuality and suggested that she favored only inappropriately young women such as the "girlish" Leonard. ${ }^{11}$ In her published accounts, Sullivan omitted that the policewomen had in fact visited the tearoom on three occasions in attempts to make Adams' acquaintance. ${ }^{92}$ Through this dissemblance, the policewoman inverted the reality of the state's aggressive pursuit of its queer female residents.

On her third visit, Leonard arranged to attend a matinee with Adams and allegedly, "en route in a taxi from the tea room to the theater, the woman spoke flatteringly of the policewoman's charms, addressed her in endearing terms, and embraced and caressed her," kissing her "so ardently in the taxi that several policemen became interested, and [Leonard] had to wave her handkerchief as a signal not to interfere." ${ }^{93}$ While Sullivan surely embellished the account, policewoman Leonard implicated her own reputation, recalling in later testimony that Adams placed her hands "under my coat and on my breast" and "kissed me profusely."94 After the theater, Leonard and Adams went to a restaurant and danced a waltz, before returning to the Washington Square apartment, where Adams gifted the policewoman a copy of her selfpublished collection of studies Lesbian Love. According to Leonard, the five-foot-tall Adams

\footnotetext{
${ }^{87}$ Chauncey, Gay New York, 18; George Chauncey, "Christian Brotherhood or Sexual Perversion? Homosexual Identities and the Construction of Sexual Boundaries in the World War One Era," Journal of Social History 19, no. 2 (Winter 1985): 189-211; Sherry Zane, "II Did It for the Uplift of Humanity and the Navy': Same-Sex Acts and the Origins of the National Security State, 1919-1921," The New England Quarterly 91, no. 2 (2018): 279-306; Brian Donovan, Respectability on Trial: Sex Crimes in New York City, 1900-1918 (Albany, NY, 2016), 141-76.

${ }^{88}$ Estelle Freedman, "The Prison Lesbian: Race, Class, and the Construction of the Aggressive Female Homosexual, 1915-1965," Feminist Studies 22, no. 2 (Summer 1996): 397-423; Sarah Potter, “Undesirable Relations': Same-Sex Relationships and the Meaning of Sexual Desire at Women's Reformatory during the Progressive Era," Feminist Studies 30, no. 2 (Summer 2004): 394-415; Cheryl Hicks, “Bright and Good Looking Colored Girl': Black Women's Sexuality and 'Harmful Intimacy' in Early-Twentieth-Century New York," Journal of the History of Sexuality 18, no. 3 (Sep. 2009): 418-56.

${ }^{89}$ Cookie Woolner, "Woman Slain in Queer Love Brawl': African American Women, Same-Sex Desire, and Violence in the Urban North, 1920-1929," The Journal of African American History 100, no. 3 (Summer 2015): 410, 422; Christina Simmons, "Companionate Marriage and the Lesbian Threat," Frontiers: A Journal of Women Studies 4, no. 3 (Autumn 1979): 54-9.

${ }^{90}$ Sullivan referred to Eve Adams under the pseudonym "Billie" in her account; Sullivan, My Double Life, 207. See also Chad Heap, Slumming: Sexual and Racial Encounters in American Nightlife, 1885-1940 (Chicago, 2009), 357.

${ }^{91}$ Sullivan, My Double Life, 199, 207; Freedman, “The Prison Lesbian,” 401; Hicks, "'Bright and Good Looking Colored Girl,"” 453.

${ }^{92}$ Federal Deportation Hearing at the Women's Workhouse, Welfare Island, overseen by inspector Thomas Conroy, "Record of the Hearing in the Case of Chawa Zlotchover Alias Eve Adams" (24-30 Nov. 1924$), 12$. Courtesy of Barbara Kahn via Steven Seigel, of the Buttenwieser Library of 92nd Street Y.

${ }^{93}$ Sullivan, "The Tea Room Case," 5-6.

${ }^{94}$ Federal Deportation Hearing, "Record of the Hearing in the Case of Chawa Zlotchover," 14.
} 
then thrust her onto the bed and tried to become intimate with her, at which point the policewoman made her excuses to signal other police officers. As in abortion cases, the policewoman's body was implicated in the investigation, suggesting the complex interplay between Leonard's exploitation within the masculine institution of policing that sought to instrumentalize women's bodies as tools of surveillance, and her own agency and pursuit of professional advance. When the NYPD raided the tearoom, they arrested Eve Adams. ${ }^{95}$

The policewomen next encountered Adams in a deportation hearing at the women's workhouse on Welfare Island in November 1926. Following her arrest, Adams was sentenced for the crimes of disorderly conduct and authoring an indecent book, during which time the federal government issued a warrant for deportation. There existed no legal grounds to exclude women based on same sex desire; nonetheless, in this era immigration officials experimented with different clauses to exclude queer people at the border. ${ }^{96}$ Inspector Thomas Conry presided over the hearing that grappled with queer female sexuality; the court asked if anyone had ever accused Adams of "practicing Sapphism" and whether she tried to "make love" to policewoman Leonard, but they spent more time tying her case to prostitution. First, Conry suggested Adams ran a brothel, second that she personally sold sex, and third, that she participated in the "white slave" traffic, asking if during her a 1925 visit to Poland she tried "to bring

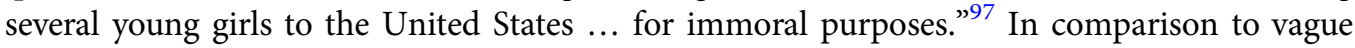
notions of queer female sexuality, immigration officials possessed tools to regulate prostitution and immigration officials co-opted the accusation of selling sex to deport a range of nonmarried women. ${ }^{98}$ Here, they attempted to apply these rules to Eve Adams.

Although the policewomen took pains to characterize the tearoom proprietress as having unrestrained sexuality, she was stoic in her court appearances, firmly rejecting the charge of prostitution. What is more, policewomen's investigations sought to persecute not just Adams, but the whole tearoom clientele and broader queer community. But Eve Adams refused to give the names of anyone else associated with the tearoom or involved in publishing Lesbian Love. "She had stood pat," Variety reported. Like the midwives, she mobilized her community to contest her arrest. Adams's uncle, Alexander Migdall, a U.S. citizen who lived in Connecticut, appeared at the hearing and spoke to her character: "I certainly do not believe that she is guilty of prostitution" and "I vouch that any book written by my niece, according to her good character and reputation, could never be immoral." Migdall also offered to furnish her bond of $\$ 1,000 .^{99}$

Amid the confusion about the appropriate charge and accusation of prostitution, policewomen made the case for deportation. Margaret Leonard emphasized Eve Adams' gender transgressions in paying for dinner and the theater (something she denied) and also her same sex desire, in keeping "her arm around [the policewoman's] shoulder all thru the performance." At one point in the hearing, when Adams' attorney questioned "how are you qualified to state [tearoom customers] are degenerates?" Leonard argued that "her own judgement" prevailed. ${ }^{100}$ In their testimony and published accounts, policewomen Leonard and Sullivan asserted themselves as the only necessary arbiters of queer women's sexuality and criminality. The immigration inspector decided there was insufficient evidence for the charge of prostitution,

\footnotetext{
${ }^{95}$ Sullivan, My Double Life, 208.

${ }^{96}$ Jack Kenny, "Modern Eve Adams Driven from Eden," Daily News, Dec. 7 1927, 4; Margot Canaday, The Straight State: Sexuality and Citizenship in Twentieth-Century America (Princeton, NJ, 2009), 25-6, 52-4.

${ }^{97}$ Federal Deportation Hearing, "Record of the Hearing in the Case of Chawa Zlotchover," 18.

${ }^{98}$ Deirdre Moloney, "Women, Sexual Morality, and Economic Dependency in Early U.S. Deportation Policy," Journal of Women's History 18, no. 2 (Summer 2006): 95-122.

99“"Eve Addams' Ring of Rich Cultists," Variety, July 28, 1926, 37. Federal Deportation Hearing, "Record of the Hearing in the Case of Chawa Zlotchover," 9-10.

${ }^{100}$ Federal Deportation Hearing, "Record of the Hearing in the Case of Chawa Zlotchover," 15.
} 
but "the testimony of the policewoman ... tends to show that this alien is a degenerate." On December 7, 1927, the United States government deported Eve Adams. ${ }^{101}$

\section{Conclusion}

By virtue of their gender and class, policewomen claimed a unique position and power in the punitive infrastructure erected to control female sexuality and reproduction in the Progressive Era. On one hand, the NYPD instrumentalized policewomen's bodies to extend state power. If women wished to challenge the status quo, they faced backlash from the male-dominated hierarchies in policing-for instance, when Mary Sullivan fought to improve matrons' status or when Ellen O'Grady pursued two wealthy men for sexual assault. But gender also underpinned policewomen's success and mobility in the profession, and in turn these professionals devised feminine modes of surveillance that increased the state's capacity to criminalize female sexuality.

Although policewomen professed an ethic of "prevention and protection," an analysis of their cases shows that for marginalized women, they often represented punishment and control. ${ }^{102}$ Policewomen wielded a different professional toolkit than male officers, which included not just the instruments of welfare and social assistance, as typically argued, but also significant carceral and punitive power. ${ }^{103}$ Indeed, for many, this proved key to both their public personas and professional identities. As Mary Sullivan explained in the final page of her autobiography, any "social services features" of the job were secondary to "the excitement, the danger" she felt when stamping out crime; "few things in the world" were "more thrilling" than "the moment of revealing [her]self to a trapped and startled crook as a woman detective."

Elizabeth Evens is a PhD candidate at University College London, UK, and her thesis, entitled "Regulating Women," examines early female entrants to medicine and law enforcement and their surveillance of other women's reproduction and sexuality.

\footnotetext{
${ }^{101}$ Ibid., 20-1. After leaving the U.S., Adams lived in Poland before saving the money to finance a move to Paris. Upon the outbreak of World War II, she moved to Italian-occupied Nice to avoid the Nazi persecution of Jewish Europeans. In 1943, when Italy allied with Germany, Eve Adams was deported once again, this time to Auschwitz-Birkenau, where the Nazis murdered her upon arrival. Playwright Barbara Kahn did much to recover Eve Adams' story in her corpus of work. Adams' life is the subject of a forthcoming biography by Jonathan Ned Katz. See Reina Gattuso, "The Founder of America's Earliest Lesbian Bar Was Deported for Obscenity," http:// www.atlasobscura.com/articles/what-was-first-gay-bar (accessed Aug. 24, 2020).

${ }^{102 ، E d i t o r i a l, ' ~ I A W P ~ B u l l e t i n, ~ M a y ~ 1925, ~ 7 ; ~ K a l i ~ G r o s s, ~ “ A f r i c a n ~ A m e r i c a n ~ W o m e n, ~ M a s s ~ I n c a r c e r a t i o n, ~ a n d ~ t h e ~}$ Politics of Protection,” Journal of American History 102, no. 1 (Jun. 2015): 25-33.

${ }^{103}$ Muncy, Creating a Female Dominion, 109-10.

${ }^{104}$ Sullivan, My Double Life, 302.
} 